\title{
The Influence of Le Corbusier On the emergence of the Aesthetic Values in the Modern Architecture of Cyprus
}

\author{
*Ph.D. Candidate FARHAN ABDULLAH ALI
}

Department of Architecture, Girne American University, North Cyprus

\section{ART I CLEINF O: \\ Article history: \\ Received 02 July 2017 \\ Accepted 21 July 2017 \\ Available online 21 July 2017}

Keywords:

Le Corbusier;

Modernity;

Aesthetic Values;

Cypriot architecture.

This work is licensed under a

Creative Commons Attribution

- NonCommercial - NoDerivs 4.0. "CC-BY-NC-ND"

E mail: farhanali@gau.edu.tr

\begin{abstract}
A B S T R A C T
Modernity has significantly influenced the branches of human knowledge; architecture has a substantial share in this effect. Modern architecture, in turn, was not a negative recipient to impact, but it was a positive catalyst for decades. Moreover, it did not limit to certain geographic boundaries, but it has spread all over the world and Cyprus was not an exception. Due to most of the Cypriot pioneer architects were studied in Europe; Cyprus was the incubator that has many architectural distinctive pieces of evidence of modern architecture. Perhaps the expert reader of the modern architectural discourse of Cyprus could distinguish numerous aesthetic features in Cyprus Buildings especially the private residences and their appearance is credited back to one of the pioneers of modern architecture; Le Corbusier. The research paper is an attempt to determine the influence of the principles that Le Corbusier claimed as keystones of modern architecture in early twenty century and how impressed on the emergence of aesthetic values of the modern architecture of Cyprus as well. The paper takes two works of Neoptolemos Michaelides, as case study (Neoptolemos Michaelides is considered the father of Cyprus modern architecture). The first case study is his and wife private residence, which considers the icon of the modern residential architecture of Cyprus and the other is the first residential project designed by him Theotodos Kanthos residence. JOURNAL OF CONTEMPORARY URBAN AFFAIRS (2018) 2(1), 1-12.

https://doi.org/10.25034/ijcua.2017.3651
\end{abstract}

www.ijcua.com Copyright (c) 2017 Journal Of Contemporary Urban Affairs. All rights reserved.

\section{Introduction}

Modernity as a lifestyle has started to construct its features through enlightenment era and had manifested as a fundamental issue where the age of machine was begun. The phenomenon of Modernity embodied in a broad spectrum of knowledge and behaviors socially, culturally and economic. Architecture Might consider the most physical appearance of human being, for that, it influenced highly by the new trends. The crystal palace, which constructed in 1851, represents the first Avantgrade example of using new construction material such as concrete, glass and steel and chronically, it was the first embody of modern

\footnotetext{
*Corresponding Author:

Department of Architecture, Girne American University, Turkey E-mail address: farhanali@gau.edu.tr
} 
architecture. In the early years of twenty century, many architects Fed up with the decorative Art Nouveau architecture and the limited horizon of the regional architecture that prevailed in that period.

As they were carrying avant-garde ideas, those architectural approaches were no longer able to accommodate future of vision toward global modernity. Le Corbusier was the forefront of those architects wherein 1923; he declared his five principles (the pilotis, the free plan, the free façade, the horizontal ribbon windows and the roof garden) which were the keystones of the Avant-garde language.

Rationality and functionality were the most obvious characters of modern architecture. These features have many aesthetic values, which distinguish the Avant - grade architectural discourse such as abstraction, purism, and Simplicity.

Le Corbusier was not just the forefront and pioneer modernist architect; he is also the most influential figure on successive generations of architects. Whereas Modern architecture did not limit to certain geographic boundaries, but it has spread all over the world and Cyprus was not an exception. Due to most of the Cypriot pioneer architects were studied in Europe; Cyprus was the incubator that has many architectural distinctive pieces of evidence of modern architecture. The works and principles of Le Corbusier have affected those architects on many levels, functionally, formally, aesthetically and technically.

This influence is the core of this research paper to detecting how it contributed in highlighting the aesthetic values of modern dwelling architecture in Cyprus. And more deeply, the study focuses on two cases study as distinguishable examples of privet residences.

\subsection{The modernity, modernism and modern architecture}

The enlightenment age highlighted the social attitude to adopt new thoughts and lifestyle, and unfolded a desire for change and looking for a modern way of living. Whereas "Modernity is what gives the present the specific quality that makes it different from the past and points the way toward the future. Modernity is also described as being a break with tradition, and as typifying everything that rejects the inheritance of the past."(Heynen, 1999, p.9) famously Walter Benjamin defined modernity as 'the world dominated by its phantasmagorias'. (Frisby, 2004, p.13) This avant-garde and conflict viewpoint with tradition had developed and spread increasingly at the machine age which inspires the artists and architects as such as the economists and politicians. The modernity movement progressed and theorized to be a philosophical doctrine; (modernism) which "refers to an international tendency that came to expression in western literature, theatre, music, visual arts and architecture in the latter half of the nineteenth century, and continued to dominate twentieth century art" (Frisby, 2004, p.23)

With The crystal palace, which constructed in 1851 (figure 1) that recognized as the ancestor of Modern architecture evidence, a new generation of construction manners and concepts, meanings and technology was begun.

Richard Lucae, published an article at 1869 , titled "On the Meaning and Power of Space in Architecture." He described the crystal palace as "a "piece of sculpted atmosphere" in which light fills the whole space with a "beautiful naturalness," a "magically poetic form of light."." (Mallgrave, 2005, p.197)

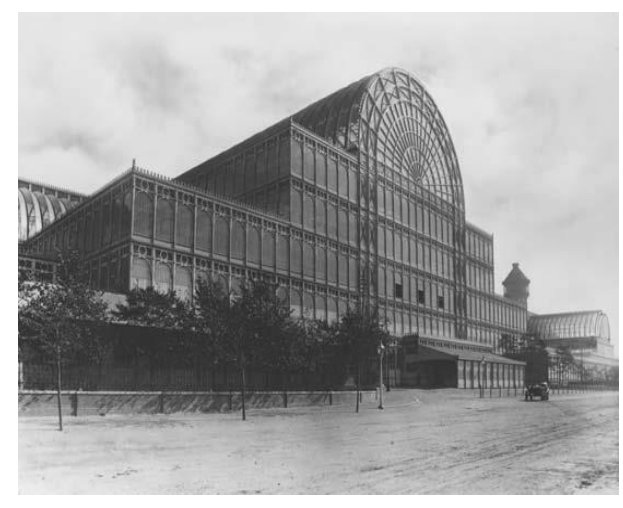

Figure 1. The crystal palace 1851. 
The machine age features after the industrial revaluation have supported new aesthetic values portray the functional attitude of the modern architecture. "At a deeper level still, industrialization transformed the very patterns of life and led to the proliferation of new building problems - railway stations, suburban houses, skyscrapers for which there was no precedent." (Curtis, 1982, p.14)

In 1896, Otto Wagner published in Vienna what is probably the first modernist architectural manifesto - his Modern Architecture. Despite its theoretical weaknesses, his contemporaries read it as a rejection of the historicism of the recent past and a plea to create an architecture appropriate to modern life. (Frisby, 2004, p.3)In the manifesto, he also suggested qualities of simplicity, realistic expression of the means of construction and a respect for modern techniques and materials.

In the early years of twenty - century, many architects reacted and Fed up with the decorative Art Nouveau architecture. The reaction against Art Nouveau, which acquired increasing momentum in the first decade, was fed in part by the Arts and Crafts ideals of simplicity and integrity: by an abstract conception of Classicism as something less to do with the use of the Orders, than with a feeling for the 'essential' Classical values of symmetry and clarity of proportion: and by a sense that the architect must strive to give expression to the values of the modern world through frank and straightforward solutions to architectural problems in which disciplines of function and structure must play an increasing, and attached ornament a decreasing role. (Curtis, 1982, p.33)

Modern architecture became more strong and acceptable in the twenty-century when had supported by numerous art schools, movement and organizations such as the futurism (19091944), the De Stijl (1917-1931), the Bauhaus (1919-1933), the constructivism (1920-1932) and CIAM (1928-1959). The members of those avantgarde took upon themselves to adopt and disseminate the principles of modern architecture and constructed new architectural aesthetics when it Celebrated and glorified the new technology and materials. The Bauhaus building in Dessau (1926) itself considered an impressive evidence about how the modern product should be (figure 2). "Within its irregular plan, glass curtain walls and steel and reinforced concrete frame beat an interdisciplinary heart so that all the departments - furniture, theater, architecture, textiles, and so on - collaborated." (Sadler, 2004, p.36)

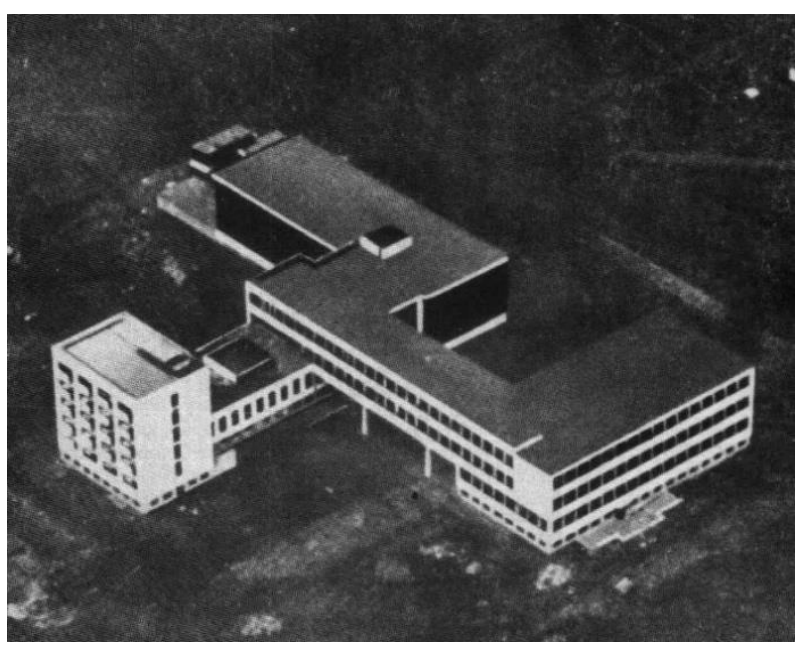

Figure 2. Bauhaus in Dessau 1921.

After World War II many architects, members of Bauhaus, and CIAM emigrated from Europe to the United States and other countries that helped to spread the principles of modern architecture around the world. In the fifteenth from the last century, the modern architecture had viciously attacked from the angry young architects that felt the pioneers had let them down and they were becoming graying establishment figures. "Only Le Corbusier remained truly inspirational to young architectural "rebels." He had no qualms about revising his principles until they were unrecognizable. He now offered what would become known as a "New Brutalism" of raw, shuttered concrete, exposed brickwork, and primitive, handcrafted-looking building techniques." (Sadler, 2004, p.40) Those 
architects tried to regain their confidence in the architecture of modernity and re-arranging the papers to draw lessons. "Under the youthful leadership of figures such as Alison and Peter Smithson from England and Aldo van Eyck from Holland, their discussion group Team 10 and practices like France's ATBAT, the supposed founding principles of Modernism were revisited in a "Brutalist" manner and new attention was paid to local rather than universal constraints. Put another way, it was possible to be in some way "avant-garde" again." (Sadler, 2004, p.40) Especially that many opponents have found a chance to ruins on the concepts and principles of modernism after criticism suffered by the modern city on the urban and social level.

\subsection{1. . Characteristics of modern architecture}

The first generation of modernists was contributed in constructing a theoretical framework of their attitude to enrich the architectural knowledge and encourage the young architects to adopt the Avant-garde movement. In their contribution, they portrayed the features and characters of modern architecture. The functionality of Luis Sullivan (form follows function), the simplicity and economic of Ludwig Mies Van Der Roch (less is more) and the openness, formality and abstraction of Le Corbusier (mass and surface are the elements by which architecture manifests itself. Mass and surface are determined by the plan. Plan is the generator. So much the worse for those who lack imagination) (Le Corbusier, 1927) all were constructed a common understanding of the purpose of the modern architecture.

The modern architect believes in simplicity in form, clarity in plan and functionality in design. The modern architectural product is characteristically free of decoration and unnecessary elements. The goals of the project are clarified at the start, and only the features that are required are included in the design. The focus will be on the space itself, rather than on any decor or details not relevant to the overall design. Also the Emphasis on the honesty of materials, there is nothing to hide, the true nature of the Materials especially the concrete, are shown in the ordinary form. Inner workings of the building tend to be visible: beams and other structural elements are exposed to the spectator. Moreover, the linear elements, rectangular forms and bold horizontal and vertical features especially the windows, staircases, rooflines, and other structural elements all contribution the architect in creating a linear-inspired open plan. Modern architecture is also characterized by an emphasis on Layout and location, which are the keys to modernist design. Building such as Chapel de Ronchamp (1955) by Le Corbusier and the falling water house by Frank Lloyd Wright are marvelous evidence on the correlation between the building and site.

\subsubsection{Le Corbusier and his principles}

It is impossible to research the architecture of the twentieth century and of our own time without first coming to terms with Le Corbusier (1887-1965). His buildings can be found from Paris to Algeria to the Punjab and his influence has extended over numerous generations worldwide. Famous building such as the Villa Savoye at Poissy 1931, the Chapel of NotreDame-du-Haut at Ronchamp 1955, Unité d'habitation, Marseille, France, 1945 and the Parliament Building in Chandigarh 1955 stand assessment with the works of any age. As well as an architect, Le Corbusier was also a painter, sculptor, urbanist, and author. Charles-Edovard Jeanneret who best known as Le Corbusier is one of the most influential architects on generations of architects after. Le Corbusier born at sixth of October 1887 in, La Chaux-deFonds, Switzerland. Son of Georges Edouard Jeanneret, watch engraver and enameller, and of Marie Charlotte Amélie Jeanneret-Perret, music teacher. He Studied watch engraving at the Art School, under Charles L'Eplattenier the director of the Advanced Decorative Arts Course (based at the Art School) whereas Le Corbusier joined to it at 1904, Charles L'Eplattenier was the person who interests Le 
Corbusier in architecture. ${ }^{1}$ In his early year, Le Corbusier designed a few villas regarding the regional style that was common in La Chauxde-Fonds also he worked as watchcase designer. The trips to Germany, France, and meditation countries that he made when he was young changed his vision about architecture and design. He worked one year for Auguste and Gustave Perret as draughtsman, half time at 1908 And another year in 1910 for Peter Behrens's architectural practice in Berlin. Then from 1912, he started his independent career. In 1914, Le Corbusier designed a skeletal structure for his Domino houses, as a technical solution to the lack of residences according to the destruction of world war I. with the aim of liberating space from the limitation of load bears. This type of thought and tendency in design was a beginning for a new vision toward construction methods (figure 3).

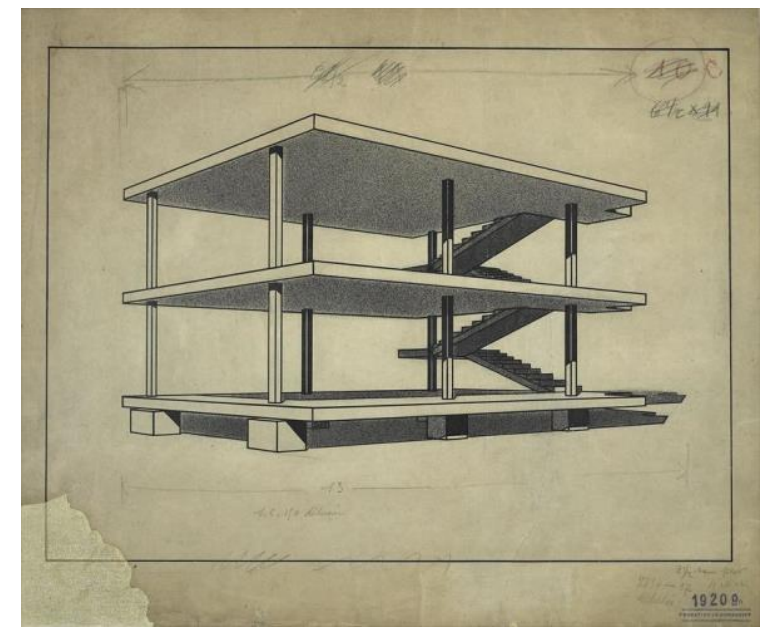

Figure 3. Domino house by Le Corbusier 1914.

At the same time, he started to document his concepts and principles about modern architecture in written way. In 1926, he published, "Les 5 points d'une architecture nouvelle" (Five points of a new architecture), which affirmed his architectural type-features: pilotis (columns), free plan, free facade,

1 For more information about le Corbusier biography, visit: http://www.fondationlecorbusier.fr/corbuweb/morpheus.aspx?sysId=11\&sysLangu age $=$ fr-fr\&sysParentId=11\&sysParentName=home \&clearQuery $=1$ horizontal sliding windows, and roof garden. (Mallgrave, 2005, p.259) after that manifesto, his reputation as Avant-grader architect started to shine

One year late, he Published Vers Une Architecture (based on articles published in L'Esprit Nouveau), published in English in 1927 as Towards a New Architecture. In 1928, he was a Founder member of CIAM (Congrés Internationaux d'architecture moderne) at the castle of La Sarraz, in Switzerland. CIAM and Bauhaus had a crucial role in constructing the principles of modern architecture (Amen, 2017). In 1930, he gained the French nationality. Le Corbusier was almost thought about the social sense of architecture and human scale, in 1945, he awarded Honorary Doctorate in philosophy and mathematics of the University of Zurich regarding years of researching on the modular, which is a represented standard for construction depending on human scale. In the rest of his life, Le Corbusier designed about 500 projects, involved, architecture and urban planning. A few of them were built and about 75 buildings reflected his vision and philosophy. Through his fruitful life, he received many Honorary Doctorates and titles and lectured at famous architectural schools. On 27 August 1965, Le Corbusier dies by a heart attack while swimming at Cap-Martin.

In Towards New Architecture Le Corbusier posed the question 'from what is emotion born?': 'From a certain harmony with the things that make up the site. From a plastic system, that spreads its effects over every part of the composition. From a unity of idea that reaches from the unity of the materials used to the unity of the general contour'. (Le Corbusier, 1927)

This 'unity of idea' is central to Le Corbusier's work - a desperate attempt to create order in what he perceived to be a fragmented and chaotic world. (Samuel, 2007, p.1) Corbusian principles might distingue in his whole projects in different level especially in Villa Savoye (19281931) (figure 4), where the pilotis are fully brought into play and are teamed with the staircases and ramps; it is a masterful creation, if 
only for its minimalist, purist language. The free plan that allows connecting spaces together with no visual obstacles then arising upstairs by attracting ramp from inner semi-court to the roof garden, seeing the outdoor landscape through the horizontal windows, a lived experience journey presented to the viewer.

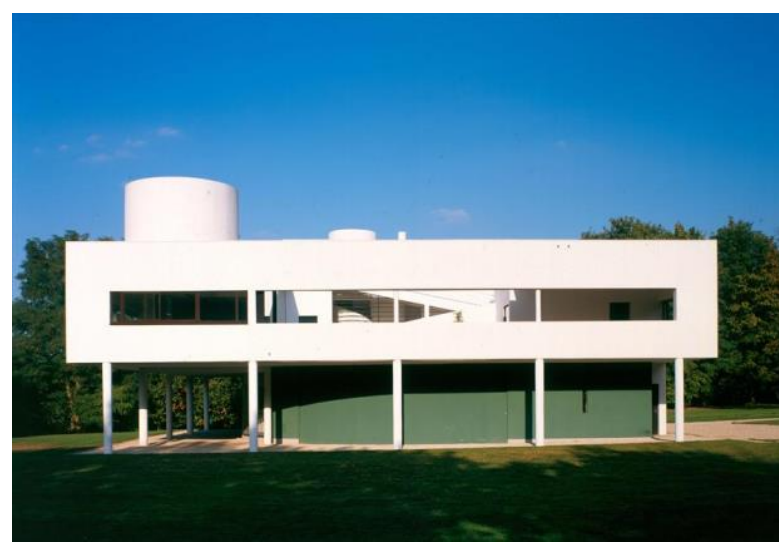

Figure 4. Villa savoye 1928-1931

\subsection{Aesthetics of Modern Architecture}

Aesthetics as "the study of the nature of beauty, especially in arts such as painting and architecture." 2 has a significant attention of many theorists and philosophers, from Socrates through Aristotle and Plato, then Kant, Nietzsche, Hegel and Heidegger to recent days. Albeit "Aesthetics is a late-emerging subdiscipline within philosophy and during the last three centuries has been for the most part considered inferior to logic and epistemology, as well as to ontology and ethics." (Sepp and Embree, 2010, p.15)

Historically, the first formal classification of aesthetics as a branch of philosophy appeared in 1735 when Alexander Baumgarten published his Meditationes philosophicae de nonullis ad poema pertinentibus - (Philosophical meditations on some requirements of the

\footnotetext{
${ }^{2}$ Retrieved from:
}

http://www.macmillandictionary.com/dictionary/british/aesthetic_2\#aest hetic_2_2 poem) and in which he identified a theory of sensibility labeled aesthetics as a desideratum. Due to Baumgarten, we find for the first time in the history of philosophy the notion of aesthetics as an in- dependent philosophical discipline (Nia and Atun, 2016). Regarding modern architecture, Aesthetics of the machine was the essential tendency of the new epoch; rationality and simplicity are the clearest features of the aesthetic values. Sadler sees "The embrace of the expressive aesthetics of modern life, whether of machinery or popular culture, that motivated Modern architects quite as much as rationality." (Sadler, 2004, p.37))The new aesthetics of modernity also involves the formal principles such as (planar surfaces and clean lines). (Mallgrave, 2005, p.232) the British historian Reyner Banham reduced this juxtaposition to twin categories, the "Academic" and the "Mechanistic." In the first of these he placed the "Three Reminders to Architects" (mass, surface, plan) as well as the chapter on "Regulating Lines," both of which derive from Le Corbusier's purist aesthetics and revolve around his definition of architecture as "the masterly, correct and magnificent play of masses brought together in light. (Mallgrave, 2005, p.256)

\section{Le Corbusier influence on the modern architecture in Cyprus}

Cyprus is the third largest island in the Mediterranean, it locates at the southeastern edge of the Mediterranean, at the crossroads of Europe, Asia, and Africa, Cyprus has had many different cultures constructed on the island throughout history where many people passed through. In Cyprus, the past lives sideby-side with the present in a unique fabric. The classical architecture of Cyprus has the same variety, which originated to the cascade civilizations had passed there. Although Cyprus did not affect by industrial revolution so much, regarding its location, which reflected negatively on the development of the infrastructure in every Cypriot city. Nevertheless, modern architecture began to be made known 
to Cyprus in the 1930s, when professional European- educated architects started to establish theirs applies on the island. In the period from the end of World War II until 1960, modern architecture has been a distinctive presence in Cyprus. Those architects were influenced by avant-garde movement in the first half of twenty-century and the works of the pioneers of modern architecture Especially Le Corbusier.

Although Unfortunately, Le Corbusier did not realize any project in Cyprus, However, more or less obvious traces of Le Corbusier can be encountered in Cyprus from the 1930s onwards. (Kiessel, M., 2014) 3

This paper will discuss the influence of Le Corbusier from different viewpoints related all with the aesthetic values of Le Corbusier's architectural discourse. First, the formal aesthetics, second the free plan organization, third, the structural aesthetics, fourth, the technical solutions and finally, the details scale. Focusing on two residential cases study designed by Neoptolemos Michaelides.

\subsection{Neoptolemos Michaelides dwelling projects:}

Neoptolemos Michaelides (1920-1993) is an important representative of the modern movement in Cyprus, with a strong personal style. He studied in Milan at the beginning of the 40's, under great architects like Gio Ponti and Bruno Zevi. He returned to Cyprus after the end of World War II that standing excuse to interrupt briefly his studies and turns in Cyprus until 1947. He then returned to Milan to complete his studies, turning in Cyprus in 1952 with the title of Doctor of architecture. In 1979, he founded the Cyprus Architectural Heritage Organization, of which it becomes the President, managing to pass on to the architects of the 80s the love of

\footnotetext{
${ }^{3}$ Direct and indirect influences of Le Corbusier on the architecture of Cyprus; a paper presented by Marko Kiessel through A Swiss in the Mediterranean, International Le Corbusier Seminar, organized by Cyprus International University - Nicosia. 2014
}

folk architecture, thus saving several important buildings in both urban and rural areas. His own private house in Nicosia is considered a masterpiece, which exemplifies the peak of his creative career.

Through his work, the architect achieved the harmonious coexistence of an environmentally sensitive and climatically correct design, while at the same time his architectural creations are of a high aesthetic level. (Michael, 2006)

\subsection{The Case Study}

The research paper focuses on two cases study as distinguishable examples of privet residences the first one is the Neoptolemos and Maria residence, the second is Theotodos Kanthos residence. The two examples were designed by the modernist Cypriot architect Neoptolemos Michaelides at the middle of last century, both of them are clear examples of the applying the principles and aesthetic values of modern architecture.

\subsubsection{Aesthetic values of Neoptolemos and Maria residence}

The family house, which Michaelides built for himself and his wife Maria during the mid1960s, located in south part of Nicosia. It was designed to be used, except for housing, and as a working space for himself and his artist wife. It also features a gallery space, where it would be exposed paintings and other collections. The importance attributed to the architect is evident in matters relating to natural light, as well as to the proper location and orientation of the building. (Figure 5)

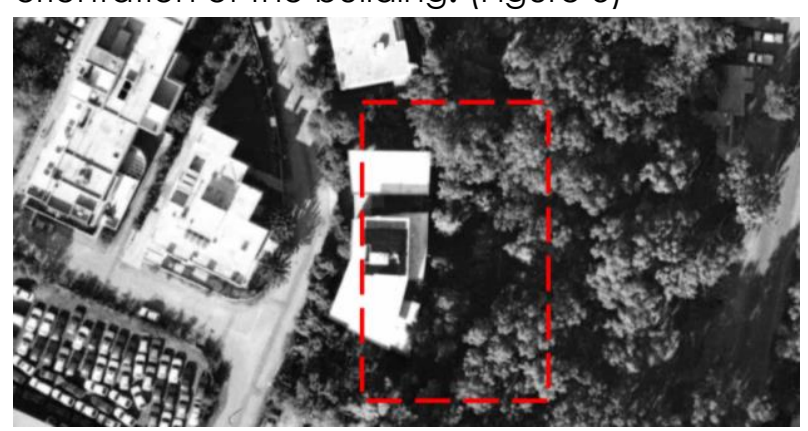

Figure 5. Neoptolemos and Maria residence- top view. 
The house stills in its original state and closed to the public since the couple passed away, the building is now under state control and the Maria and Neoptolemos Michaelides Foundation. The brutalist appearance of the house remains a strong evidence of its time. "The modernist treasure composed of concrete overhanging slabs, a vaulted roof, expanding terraces, sculptural staircases and glass surfaces are untouched and tell the story of this highly creative couple. The interior of the house highlights pure and simple volumes, graphical concrete surfaces and wooden features such as railings reminding the old prehistoric elements." 4

"It is worth noting the variety at play across the villa's three stories. The parking spaces and quests living areas at ground level contrast a far more reserved second floor, the piano nobile, comprising living quarters for the owners. The third floor, an isolated den for study, is crowned by a beautifully articulated at the top slab parabolic vault." 5

In this house seemingly, N., Michaelides had influenced by Le Corbusier on efferent levels; on the principles level, we could notice that he applied three of them: the pilotis, the open plan, and the free façade. On the formal level also we could notice another Corbusian feature is used; the vault slab which it appears Cleary in many building designed by Le Corbusier such as Maison Jaoule and Villa Sarabhai before(figures $6,7,8,9)$.

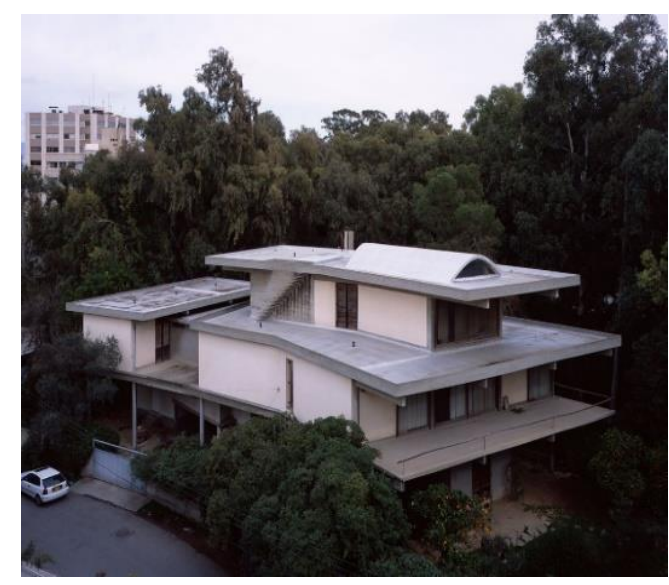

Figure 6. Neoptolemos and Maria residence.

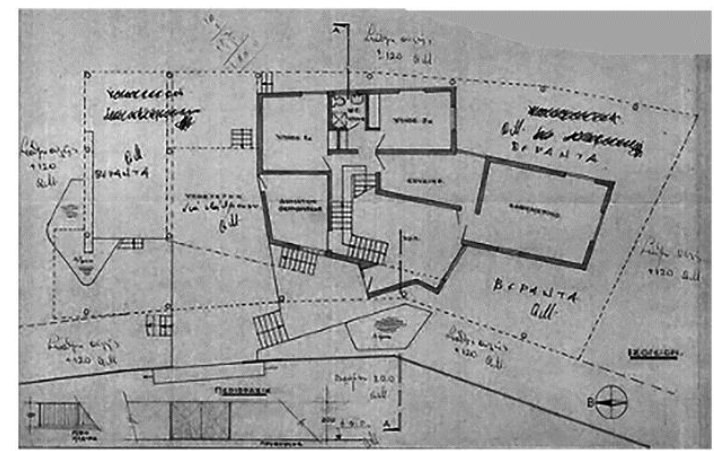

Figure 7. Ground floor plan / Neoptolemos and Maria residence ${ }^{6}$

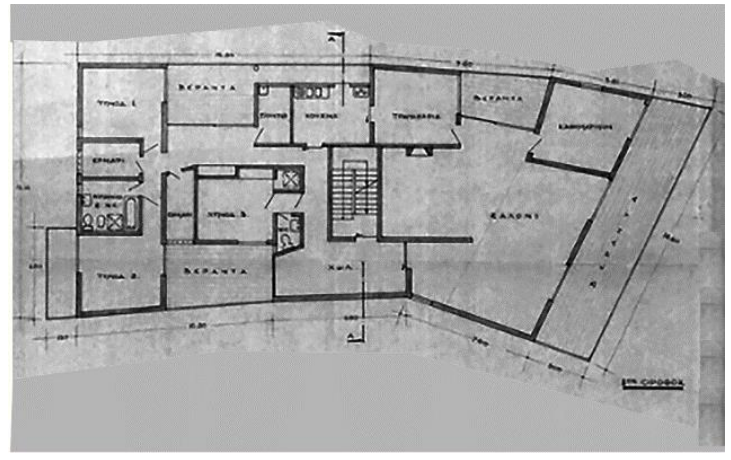

Figure 8. First-floor plan.

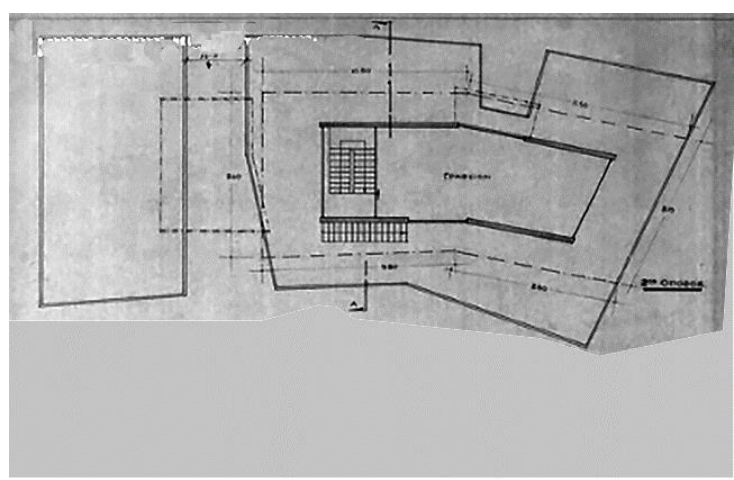

Figure 9. second-floor plan.

\footnotetext{
${ }^{6}$ Retrieved from https://www.flickr.com/photos/petrosphokaides/
}

\footnotetext{
${ }^{4}$ Retrieved from http://www.coolhunting.com/design/helene-binetneoptolemos-michaelides

${ }^{5}$ Retrieved from http://www.cy-arch.com/neoptolemos-michaelides- 


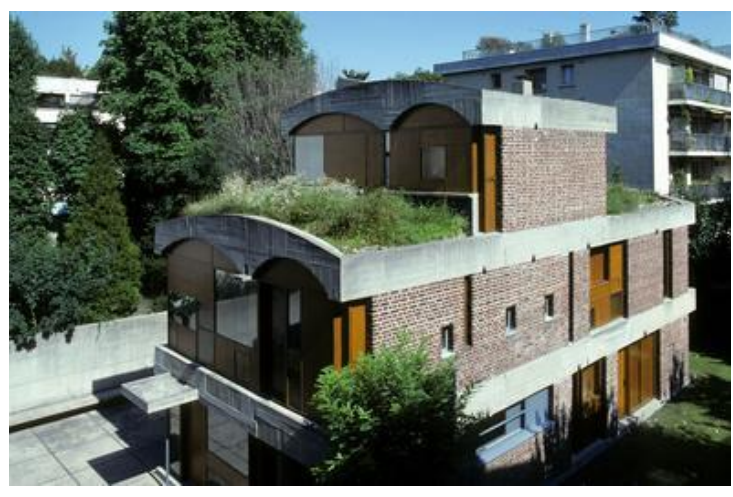

Figure 10. Maison Jaoule-exterior.

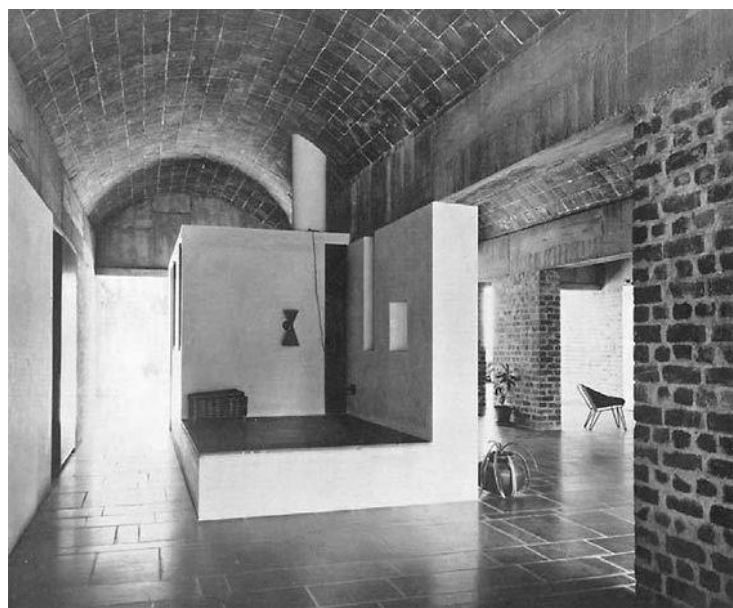

Figure 11. Villa Sarabahi - interior.

On the materials and details level, he used the big glasses with upper ribbon windows that Le Corbusier used in Villa Savoye 1928-1931. Regarding the materials, he had used the traditional material such as wood with modern ones such as concrete, steel, and class insofar Le Corbusier tactic especially in Villa Sarabhai, Ahmedabad 1951. The elegant sensitivity of merge these materials together reflects the aesthetic adapting of the construction resources (Figures 10, 11).

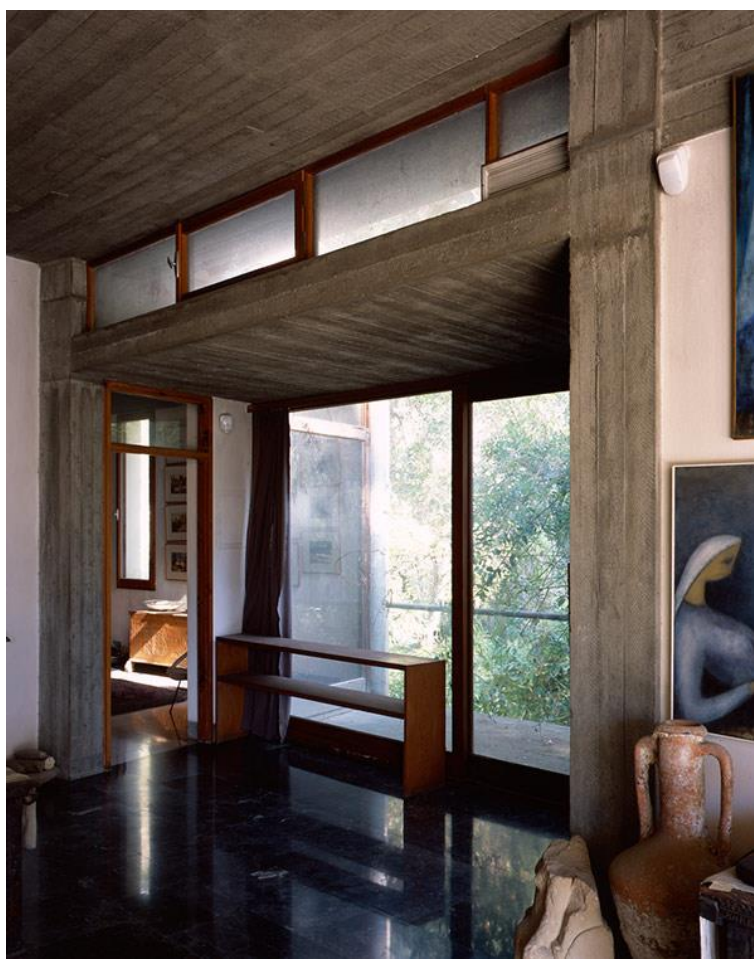

Figure 12. Neoptolemos and Maria residence 1964.

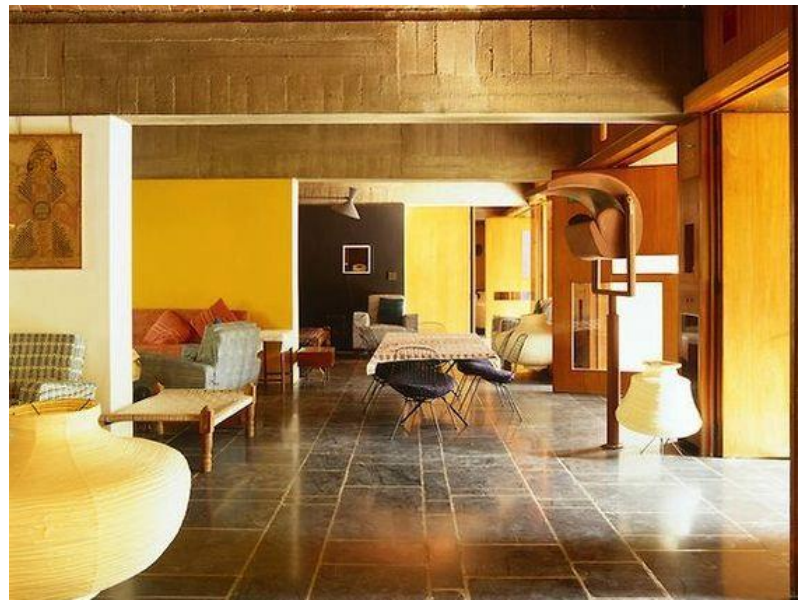

Figure 13. Villa Sarabhai, Ahmedabad 1951.

In addition, he used the concrete without plastering as Le Corbusier did in his brutalist period after WWII; moreover, obviously, he supervised and practiced his construction staff in a professional way from the level of productivity and precise working comparing with a critical time of the years of construction. Study the lighting and reflection which remind by Le Corbusier words" the elements of architecture are light and shade, walls and space" ( Le Corbusier, 1927) 
He dealt with those elements in an attractive way (figures 12, 13). moreover, N., Michaelides did not hide his influence by Le Corbusier, the elements was clear to viewers, the concrete gutter for draining rain water was used in an abstract and aesthetic way as Le Corbusier had done before in many building such as in Villa Shodhan, Ahmedabad 1951 (figures 14, 15)

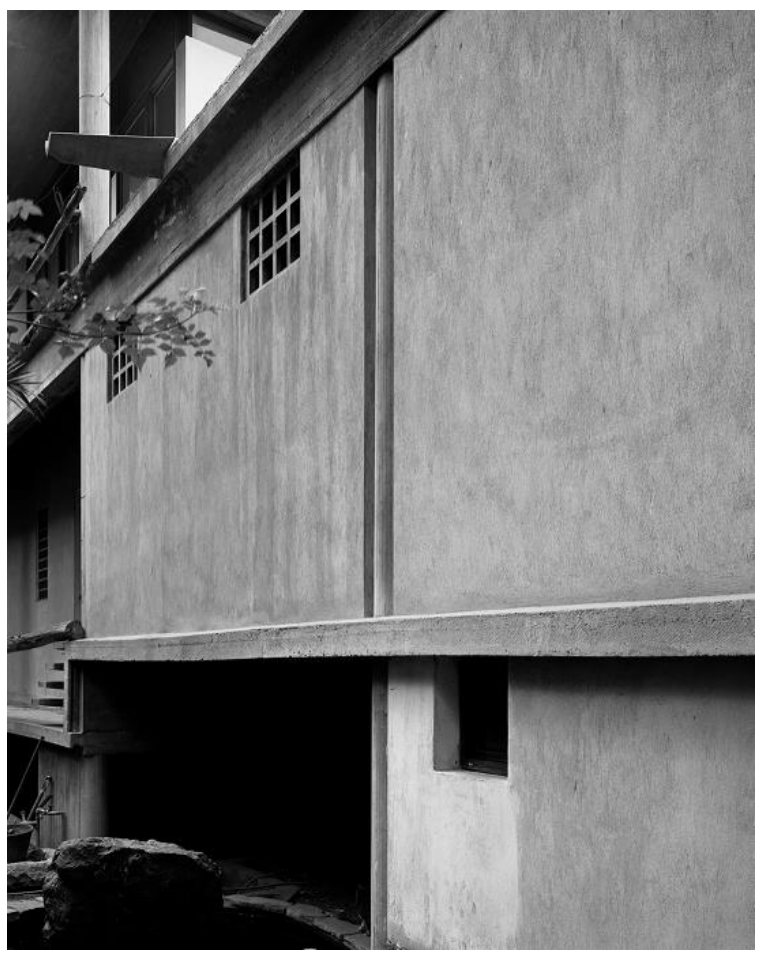

Figure 14. Neoptolemos and Maria residence, details.

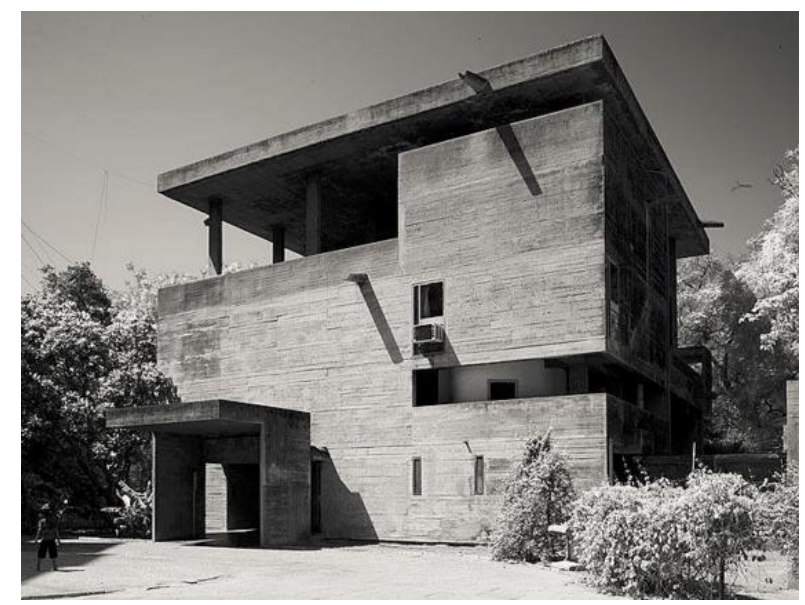

Figure 15. Villa Shodhan, Ahmedabad 1951.

In addition, the nautical large balconies, the steel handrail, and light staircase could be differentiated as aesthetic features recognize in N., Michaelides residence was used by Le
Corbusier before in many building such as his nautical metaphors in Unité d'habitation, Marseille, France, 1945 (figure 16)

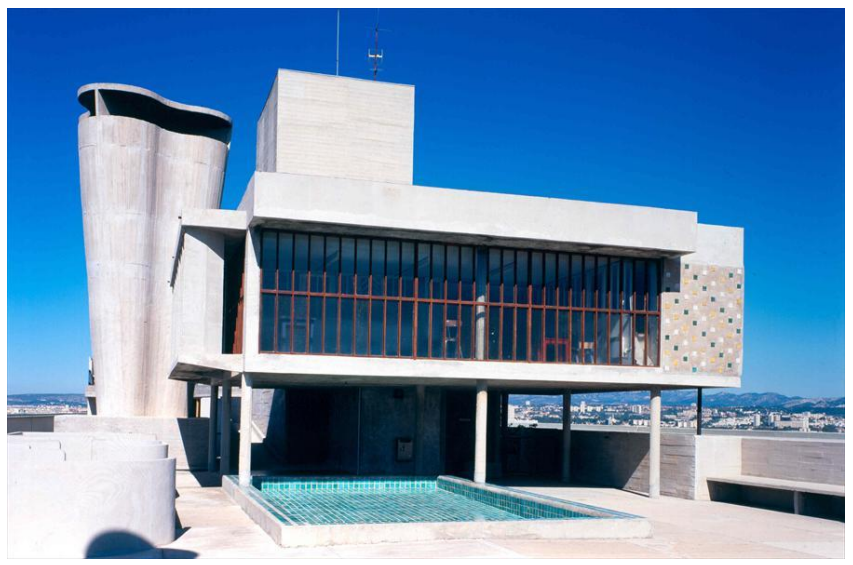

Figure 16. Kindergarten on roof in Unité d'habitation,

Marseille, France, 1945.

\subsubsection{Aesthetic values of Theotodos Kanthos residence}

This project is the home of the painter and close friend Theodotos Kanthos; perhaps it was the first architectural example in Cyprus that embraces so overall the principles of modern architecture. The House Designed in 1949 and its construction was completed in 1952. This is a three-bedroom house, further comprising painting atelier (Figures 17, 18).

N., Michaelides, despite his young age, in this house, he applied so impressively all novel elements of the modern movement. Apart from the residential spaces, it contains a painting studio. The usage spaces are clearly divided into two levels. The common spaces are on the ground floor, the private ones on the first floor. The passage into the interior of the building contains three stages: The covered foreground, the glassed entrance space with the vertical circulation and the closed interior space. The differentiation of the building volumes over the height determines concrete visual connections and allows for a high level of natural lighting of the spaces. During the summer period, the activities of the closed living room are transferred into the outer covered space that is defined by the structural grid, the water pond, and the curved wall, encasing the painting studio (Michael and Phocas, 2010). 
In the design, special attention was given to functional separation and transition from open to close. Moreover, the relation between outdoor and indoor, neoplastic and free view of the composition both plan view and in section where it was distinguished from its simple forms, In addition, we could notice that The architect focused on the rational use of materials, the dialectic resolving conflicts in and out, up and down, open-closed, covered-uncovered, are the tools used by the architect. He fully elevated the building on Corbusian pilotis although there were rare use piloites even to elevate a part of the building in Cyprus before the 1960s.

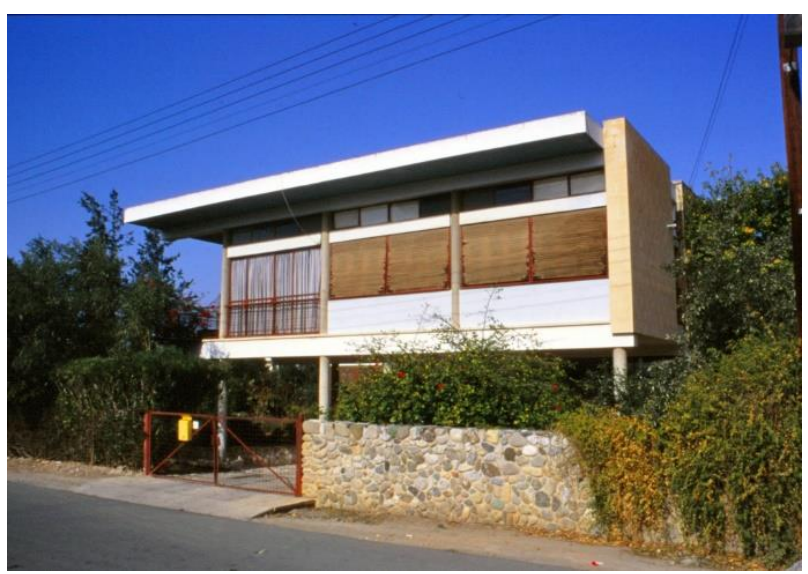

Figure 17. Theotodos Kanthos residence (1949-1952).

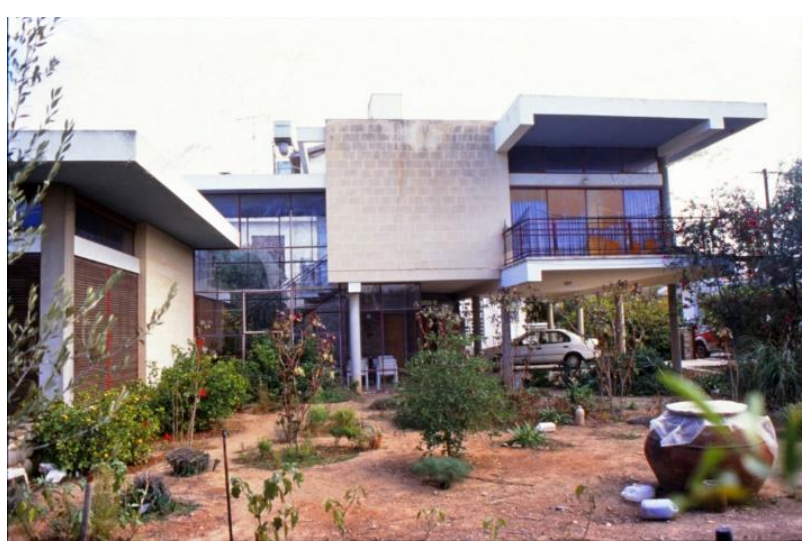

Figure 18. Theotodos Kanthos residence (1949-1952).

\section{Conclusions}

The research paper aimed to highlight on the modern architecture of Cyprus through a historical review about the appearance of modernity, and how it was affected the whole lifestyle in the $20^{\text {th }}$ century. The paper found many pieces of evidence on the emergence of aesthetic value in modern dwelling architecture of Cyprus regarding the influence of Le Corbusier principles and applying them in the modern architectural discourse by discussing two examples of private residences designed by N., Michaelides. The pilotis (columns), free plan, free facade, horizontal sliding windows, and roof garden are the most important architectural type features were used. Moreover, the simplicity, functionality, the brutalist features, the nautical elements are distinguished the modern architecture discourse of Cyprus.

\section{Acknowledgments}

This research did not receive any specific grant from funding agencies in the public, commercial, or non-for-profit sectors.

\section{References}

References

Amen, A. M. (2017). Oeuvre vs. The inspiration of Bauhaus principles on the modern housing in Cyprus. Contemporary Urban Affairs (JCUA), $1(2)$,

21-32.

\section{https://doi.org/10.25034/ijcua.2017.3645}

Corbusier, L. (1986). Toward a new architecture. (F. Etchells, Trans.) New York: Dover Publications INC.

http://store.doverpublications.com/0486250237. $\underline{\mathrm{html}}$

Curtis, W. j. (1983). Modern architecture since 1900. Oxford: Phaidon Press Limited. https://uk.phaidon.com/store/architecture/mo dern-architecture-since-1900-9780714833569/

Frisby, D. (2004). Analyzing modernity. In M.. Hvattum and C. Hermansen, Tracing modernity manifestations of the modern in architecture and the city (pp.3-22). Taylor \& Francis e-Library. Heynen, H. (1999). Architecture and modernity. The MIT Press. https://trove.nla.gov.au/work/29941163? selecte dversion=NBD25054557

Kiessel, M. (2014). 7. Direct and indirect influences of Le Corbusier on the architecture of Cyprus (unpublished paper). A Swiss in the 
Mediterranean, International Le Corbusier Seminar, Cyprus International University. Nicosia. https://www.academia.edu/23084586/DIRECT AND_INDIRECT_INFLUENCES_OF_LE_CORBUSIER ON_THE_ARCHITECTURE_OF_CYPRUS

Le Corbusier's biography (n.d). Retrieved from http://www.fondationlecorbusier.fr/corbuweb/ morpheus.aspx? sysld $=11$ \&sysLanguage $=f r-$ fr\&sysParentld $=11$ \&sysParentName=home\&clea rQuery=1

Macmillan dictionary (n.d). Retrieved from http://www.macmillandictionary.com/dictionar y/british/aesthetic 2\#aesthetic_2 2 2

Mallgrave, H. F. (2005). Modern architectural theory a historical survey, 1673-1968. Cambridge University Press.

https://www.amazon.com/Modern-

Architectural-Theory-Historical-1673-

1968/dp/0521130484

Michael, E. (2006). The bioclimatic dimension in the architectural work of Neoptolemos Michaelides. Mimarca journal 73. http://doczz.biz.tr/doc/58217/mimarcaedit\%C3\%B6r\%C3\%BCn-k\%C3\%B6\%C5\%9Fesimimarca-73-e-ba\%C5\%9Flarken

Michael, E. and Phocas, M.C. (2010). Bioclimatic approaches of modern residential architecture in Cyprus, 1952-1974. International Conference on Renewable Energies and Power Quality (ICREPQ'10).

Granada. https://www.researchgate.net/publication/3145 11917 Bioclimatic_Approaches_of_Modern_Resi dential_Architecture in_Cyprus 1952_- 1974

Nia, H.A and Atun R.A. (2016). Aesthetic design thinking model for urban environments: A survey based on a review of the literature'. URBAN DESIGN International, Vol.21 (3), pp.195-212. Palgrave Macmillan: London. https://doi.org/10.1057/udi.2015.25

Sadler, S. (2004). An avant-garde academy. In A. Ballantyne, Architectures modernism and after (pp.33-56). Blackwell Publishing Ltd. DOI:10.1002/9780470774229

Salah Muhy Al-Din, S. (2017). The influence of Mediterranean modernist movement of architecture in Lefkoşa: The first and early second half of 20th century. Journal of
Contemporary Urban Affairs, 1(1), 10-23. https://doi.org/10.25034/1761.1(1)10-23

Samuel, F. (2007). Le Corbusier in details. Oxford: Architectural Press. https://doi.org/10.4324/9780080550626

Sepp, H., \& Embree, L. (2010). Handbook of phenomenological aesthetics. Springer. https://www.springer.com/la/book/97890481247 $\underline{01}$

Stech, A.(2015). Helene Binet captures a hidden architectural gem in Cyprus. Retrieved from http://www.coolhunting.com/design/helenebinet-neoptolemos-michaelides 